\title{
Gender-oriented Budgeting as a Democratic Practice during a Self- government Reform: Ukrainian Experience
}

\author{
Ikram Aghasiev
}

Doctor of Science, Professor, Baku Business University, Azerbaijan

Nataliia Pavlikha

Doctor of Economics, Professor, Lesya Ukrainka Eastern European National University, Ukraine

\section{Nataliia Riabushenko}

Assistant Professor, V.Lipinski Volyn Institute of Interregional Academy of Personnel Management, Ukraine

\begin{abstract}
Given the European vector of Ukraine's development, the issues of decentralization and related problems of reorganization of the management system throughout the power vertical are relevant. The transformation of a self-government system in the conditions of decentralization induces the development of innovative theoretical paradigms and the implementation of the best practices, including the gender-oriented ones. Although only a few years have passed since the beginning of the administrative reform, Ukraine has both positive and negative practical experience that needs to be analyzed and generalized. It is important that, along with a of selfgovernment reform, sectoral reforms are also taking place. At the community level, the parallel implementation of reforms provides an opportunity to review both human resources (including based on gender attribute) and the use of financial resources.

A significant obstacle to reforms is the inconsistency of the regulatory framework and the pace of changes, as well as the division of powers between the different levels of the vertical (a region - a district - a community) and the horizontal (cooperation between communities to achieve strategic goals). The analysis of the community's financial capacity has shown that the departure from the initial long-term plan is not always justified and increases the risk of not being able to provide at least a minimum list of services for the population without the help of the state.
\end{abstract}

The government's medium-term planning of financial resources can be implemented at the community level through the outcome-oriented budgeting. The introduction of new approaches to the formation and use of financial resources, as shown by the experience of already established communities, provides the opportunity to "see" every male and female resident, to assess their needs and to determine how much they can be satisfied.

A key element of a gender-oriented budgeting, which is being actively introduced by the state today, is to measure the degree of influence that occurs as a result of the application of budget funds, to fulfill the tasks, to meet the needs of different groups of the population.

For a long time, new approaches to budgeting have been implemented inactivity and, often, only formally. One of the approaches, a special-purpose programme, the use of which should be mandatory for budgets of all levels since 2019, aims at optimally utilizing the mostly limited resources of the community budget to achieve maximum efficiency and highest quality of services for specific groups of women and men. An important issue is the transparency of the formation, justification of the efficiency of spending budget funds, monitoring and providing reports with specific results. The combination of the gender-oriented budgeting and the programmetargeted method, provided that a community-based self-government reform takes place, has all the means to promote the effective use of financial resources and to take into account the interests of women and men of all ages.

Keywords: decentralization, management, principles of governance, gender-oriented budgeting.

JEL Classification: G34, G31.

(C) The Authors, 2018. This article is published with open access at Sumy State University.

\section{Problem statement}

The processes of decentralization and local self-government reformation in Ukraine are aimed at improving the quality and effectiveness of the community management model, prompting to find ways to optimize it. Its result should be to ensure the sustainable spatial development of the country and its regions. Innovative 
approaches that can be used are based on a combination of investment attractiveness of the territory with environmental safety and social responsibility. At the same time, the main reference point for this innovative model should be a person with his or her needs.

The process of implementing the innovative model of sustainable development was started in Ukraine in 1994. However, due to subjective and objective reasons, ensuring the competitiveness of the economy, forming a favorable investment climate, complying with world standards for management of the economy - political, social and environmental processes have slowed down. Only political changes in the country stimulated the reformation of the management model at both levels of the state and of the community. In the Strategy for Sustainable Development "Ukraine 2020" (Order of the President of Ukraine on the Sustainable Development Strategy "Ukraine - 2020", 2015), the goal of which is to introduce world standards of life in Ukraine and to enable Ukraine to take the leading position in the world. It is stated that Ukraine should become the domain with a strong economy and advanced innovation. To gain this goal, it is important to ensure a sustainable economic growth in a non-exhaustive way, to create favorable conditions for economic activity that takes into account and meets the needs of the population, women and men of all ages.

\section{Analysis of recent researches and publications}

A significant contribution to the study of the processes of evolution of the concepts of a state and regional management has been made by Ukrainian scholars and practitioners: L. Antoniuk, G. Atamanchuk, V. Heiets, V. Ivchenko, S. Sokolenko, M. Sharko and others. However, the problems of forming a model, developing management mechanisms at the level of the territorial community are not sufficiently explored.

According to experts, the administrative-territorial reform has been "slowed down" for a long time because of the failure to consider the importance of developing and implementing a comprehensive functional analysis of the authorities at all levels with a purpose to identify and eliminate the duplication of powers, their ineffective allocation among different branches of government. There were no clear motivational measures and the normative base did not reflect changes. As a result, the reaction of key stakeholders and beneficiaries towards the reform was ambiguous.

A number of factors, including geographic and demographic potential, availability of resources including which contain human-specific features and development trends of both businesses and government institutions, provide an innovative development of a territory. However, in addition to the resource potential the synchronicity of actions, changes in all sectors of the economy and the community are of great importance. The incoherence of reforms, the discrepancy of the regulatory framework to realities of economic development are mostly noticeable in relation to communities whose representation at the decision-making level was formal until recently. According to acceleration in community sustainable development focused on results, it is advisable not only to use international experience, but also to identify and confirm the state action, clear, realistic, achievable benchmarks, which, on the one hand, will provide welfare due to meeting the needs of men and women, on the other hand, they will save the ecosystem.

\section{Parts of the general problem unsolved earlier}

A very important factor in influencing the development of the country and its regions is a management model. Today, united communities have a unique opportunity to form their own management structure, taking into account their peculiarities. Under these conditions, an effectiveness, as well as management efficiency should be seen not from the point of view of self-government officials, but from the position of the community members, their provision with innovative products and services. It is important to take into account the world experience and the experience of the communities that have been united at this time.

Models of state and regional government in Poland and Ukraine differ, but the processes of self-government reformation have a number of common features. In view of this, the works of one of the authors of the Polish decentralization reform, Jerzy Regulski, are of great interest. In his opinion, there are five significant obstacles to change. First of all, it is a political monopoly - political parties consider reform as a means of expanding their own influence, using bribery of voters sometimes (Regulsky, J., 2014).

\section{Presenting the main material}

Due to the unsettled regulatory framework, the management hierarchy of state authorities in Ukraine largely operates in accordance with the Soviet model with all the negative characteristics of the management structure. On the one hand, the hierarchical principle in building a system of public administration at all levels remained 
a priority. At the same time, the negative tendencies in the state activity continued to operate. The most obvious shortcomings of the hierarchical construction are the following:

$>$ Excessive centralization of management and, corresponding to it, directive-authoritarian methods for the adoption and implementation of managerial decisions. The regional and district levels of executive power concentrated excessive powers and a "manual mode" management from the center was used.

$>$ Regional authorities remained to be an instrument for the implementation of central government decisions.

$>$ Lower levels (rural, village councils) did not have real tools for influencing decision-making on resource planning, defining a development strategy, and the needs of the population as a whole, especially taking into account the specifics of the needs of different groups of men and women (Regulsky, J., 2014).

On the other hand, the leaders of the united communities can formally act at their own discretion, since their submission to anyone is not prescribed, which can be used in favor of not only the community but of certain business circles.

Jerzy Regulski pays special attention to the financial component. Communities' budgets have direct relations with the state budget. That is, the community can independently dispose the financial resources. However, together with the rights, it receives the responsibility for the use of funds. For small communities formed on the basis of several village councils, where their own funds were miserable, this is not an easy task today (Regulsky, J., 2014).

Another risk, according to the author, is the property monopoly. Communities have gradually received not only buildings that are often in miserable condition and require significant maintenance costs, but also a land, which increases their investment attractiveness, as well as the risks.

It is equally important to overcome the administrative monopoly. A part of the employees of state administrations become self-government workers, satisfying the personnel "hunger", but their previous experience is not always useful in the new conditions of management. After all, in the context of the decentralization reform, a management concept should be oriented to the "priority of a humanitarian and social component of public administration" (Project "Local Economic Development of Ukrainian Cities", 2012), form a new approach to understanding the principles of good governance, create such institutions that would meet not only the requirements of efficiency, but, first of all, be accessible, accountable, that is, "sensitive to the needs, requests, requirements of citizens" (Project "Local Economic Development of Ukrainian Cities", 2012). The decision-making approach should also be innovative. So, T. Kravchenko notes that the degree of development of local self-government depends, in particular, on the desire of every member of the territorial community to "help each other to realize their hopes and interests" (Kolbasiuk, Yu. V. et al., 2013). According to the scholar, the development of a territorial community can be ensured by a single, comprehensive process of a strategic planning, which "involves representatives of all parts of the community and is carried out by local government bodies and officials. It can also be an initiative of any scale and on any issue involving different groups (both formal and non-formal)".

The European Charter of Local Self-Government, adopted on October 15, 1985, and ratified by Ukraine in 1997 (Law of Ukraine "On ratification of the European Charter of Local Self-Government"; European Charter for regional democracy, 2008), consolidated the basic principles of local self-government. They are based on local democracy and autonomy, legal, administrative (organizational) and financial autonomy of local selfgovernment bodies. The process of implementing these principles continues today. The main principles and requirements, in our opinion, are as follows (Infrastructure of the regions of Ukraine. Priorities of the modernization. Analytical study, 2017):

$>$ democratic governance (Article 3);

$>$ public participation (Article 4);

$>$ subsidiarity (transfer of authority from the upper to lower levels of government) (Article 5);

$>$ proper governance and administration with an emphasis on the quality of public services (Article 6);

$>$ conceptual determination of the place and role of regional authorities (the diversity of forms while preserving the basic approaches) (Article 7);

$>$ the relationship between regional authorities and local self-government bodies (Article 8);

$>$ loyalty and respect for territorial integrity (observance of the Constitution, laws, sovereignty, national unity) (Article 9);

$>$ unity of social and economic goals of all levels of government (Article 10); 
regulation and realization of regional interests that are not excluded from the competence of the regional self-government bodies within the Constitution and laws, adoption of appropriate decisions in the case of exclusivity of their own powers, and the involvement in decision-making processes at the state level (Articles 12, 19);

$>$ freedom of action (Article 13);

$>$ adequate resource support (development of regional financial resources) (Article 16);

$>$ IT tools (e-governance).

The European experience of self-government has become, today, the basic model for the newly created communities, which will provide all members of the community with equal access to decision-making on the formation and distribution of resources.

Taking into account the European experience of self-government reform, it is still necessary to take into account the peculiarities of Ukraine's development, the significant influence of the Soviet past, which was discussed above. In addition to the consequences of the totalitarian regime, the level of decentralization, territorial and financial aspects should be directly attributed to the factors influencing the system of management of the united territorial communities (UTC). The issue of redistribution of powers on education, medicine, social sphere (as the most significant for the population, since partly related to the optimization of the network of institutions) was partially solved during 2015-2017. The ability to dispose of land became real only in 2018. Besides new approaches were used to provide administrative services to the most remote communities. There is also a large number of unincorporated communities represented by large cities, which village councils do not want to join. The latter see the threat from the city of losing control over their property, first of all, the land. The same factor is the reason for the presence of a large number of small, united communities from the village councils, which have warnings to more affluent neighbors (State website of the Decentralization).

While analyzing the decentralized management model by united communities, it is important to determine the acceptable level of decentralization, the division of responsibilities between management levels and the consolidation of sources of funding. We agree with the opinion of Bohdan Danylyshyn, who said "while changing the management model in Ukraine with a focus on strengthening local self-government, it is important to consider the problem in two areas:

$>$ territorial - determining the size of the territory in which an effective management can be provided;

$>$ financial - the management levels resources provision" (Heiets, V. M., 2006).

The European experience does not provide a clear idea of what the optimal size of the community should be for its capability and self-governance. However, in most cases, territories with larger size and population have more financial resources for providing quality services (own resources), but a significant amount of resources complicates the management mechanism.

If we analyze the experience of the first 159 communities in Ukraine (in which the elections took place on October 25, 2015), only one was formed around the city of regional significance (Limanska UTC of Donetsk region), $13 \%$ were formed around the towns of district significance, and $87 \%$ - around villages, rural and settlement councils. Accordingly, there is a risk of the impossibility of providing quality services due to the lack of establishments of a certain profile, finance, experience and appropriate staffing. Most of these communities ( $82 \%$ ) unite from 2 to 7 thousand people, the smallest of them -1.5 thousand persons (Smoligov UTC of Lutsk district, Volyn region), the largest - 39.6 thousand people (Dunaevetska UTC of Dunaevetskyi district, Zhytomyr region). They differ significantly in size: the smallest is 17.5 sq.km (Zimnivska UTC of Volodymyr-Volyn district, Volyn region), the largest is 1284 sq.km (Naroditska UTC of Naroditskyi district, Zhytomyr region). Most of them (79\%) have less than 300 square kilometers. That is, in most cases the union took place outside of the recommendations. However, this tendency emphasizes that a mechanism and a methodology must be developed that would help to solve the problems of such communities (most of them have a basic subvention) through joint efforts, for example through clusters or crowdsourcing (Official website of the programme DOBRE - "Decentralization Offering Better Results and Efficiency").

In Ukraine, there is a low level of income and, at the same time, high-income differentiation between different population groups and territories, the imbalance between budgets of different levels and their powers. Accordingly, financial decentralization can be a challenge and even a threat to a number of territories and communities. The deficit of own consolidated revenues, the uneven distribution of the tax base in Ukraine 
(VAT, excise, income tax), the mobility of the tax base (income tax) limit the advantages of high decentralization. There is a gradual increase in the tax base of revenues to community budgets.

Besides, in the framework of decentralization, the revenues of the budgets of village united communities will be replenished with $60 \%$ of the personal income tax, which today is directed at the district level. Certain activities and institutions in the educational, medical and cultural spheres, support of local councils of physical training and sports associations and their sports bases are transferred from the state to the regional and local level. New types of transfers were introduced: basic subsidy, reverse subsidy, educational subvention, subvention for workers training, medical subvention; subvention for the provision of medical measures of individual state programmes and complex measures of a programming nature, reverse subsidy.

A new horizontal leveling system has been established under the national taxes (income tax and personal income tax), depending on the level of income per inhabitant. The remaining payments are not levied and will remain in full possession of local budgets. It is envisaged that the size of the development budget should be not less than $10 \%$ of the total volume of own funds of local budgets (Budget Code of Ukraine, 2017).

All this will contribute to ensuring local budgets with sufficient revenues and will encourage local authorities to attract additional revenues and to expand the tax base. The transfer of tax powers to regions and the right to set local taxes on their own is advantageous, first of all, to high-income regions, which means that the ability to provide public services in "rich regions" will continue to be higher than in the "poor regions". That is, economically powerful regions continue to become stronger.

The introduction of budget decentralization, in most cases, is accompanied by complex management decisions: which national goals are of priority - achieving economic efficiency, social justice or macroeconomic stability? This is the so-called "triangle dilemma" (Ivchenko, V., 2009).

The ratio of local effects from the provision of public services and the effectiveness of their creation is another potential "stumbling-stone" in the implementation of budget decentralization. The risk caused by the scale effect is related to reducing the cost of a unit of the service provided with an increase in the volume of services rendered - the cost of service decreases with an increase in those who wish to receive it.

While analyzing this risk of the budget decentralization, it is necessary to clearly understand what should be the minimum size of the administrative-territorial unit, so that the ratio of price/quality of a public service is optimal, and the socio-economic effect is maximum.

In addition to the financial risks of the budget decentralization, experts allocate one more group of risks managerial. Such risks are associated with the low qualification of the administrative apparatus of local selfgovernment (especially in the financial and economic sphere), the domination of personal interests over the public, the inconsistency of the formation of local budgets with the goals and objectives of socio-economic development of territories. As a result, the use of the potential of the budget decentralization is leveled, which leads to a decrease in the efficiency of the public sector functioning.

Assessing the advantages and disadvantages of centralization/decentralization processes, it is perhaps the biggest problem to find a balance between competing approaches to budget policy implementation. Apparently, for a certain stage of development of a particular territory, there is an optimal set of parameters. In this sense, the control of the community itself, regarding the use of resources, is of particular importance, especially if they are limited (Budget Code of Ukraine, 2017; Regulsky, J., 2014).

The use of such "electronic city" system creates a convenient link between the community and executive selfgoverning bodies. Thus, the community is an active participant in making managerial decisions. A "single window" ensures fast, clear, high-quality service provision with regard to a person (gender, age, health status, place of residence, etc.). It is efficient to use this method of sharing information both through a common practice that is the joint activity of local managers and stakeholders for discussion, the search for ways to solve practical problems through public events, reports and through the use of online platforms. Other means of electronic communications - "smart communities" - become also popular. Unfortunately, some communities formed in villages cannot use e-government because of a low quality of Internet or its absence and unskilled staff.

The experience of Novopskovsk united community, which introduced the participation budget, showed that the involvement of citizens in the formation and satisfaction of needs through co-financing is the way of forming an effective, powerful community. However, the effectiveness of this tool depends on the level of formation of civic consciousness and political will of the leadership. The community executive committee has 
faced the problem of distrust, lack of awareness and as a result a lack of involvement of citizens (State website of the Decentralization).

It should be noted separately that there is a need to increase the competence of local self-government officials. Both state structures and international institutions, in particular, the Friedrich Ebert Foundation in Ukraine, UN Women, NDI (National Democratic Institute for International Affairs), SIDA (Swedish International Development Agency) played a particular role in the process of qualification development. Their work is aimed at both public activists and self-government workers. Particular attention is paid to supporting women's activity in the process of decentralization since women make up the vast majority of communities, however, they are poorly represented at the decision-making level.

One of the activities of donor organizations together with public authorities was the application of such an approach to managing the community's financial resources as gender-oriented budgeting. If it is used, the united territorial communities have the opportunity to:

$>$ orientate on the needs of the population of its own community;

$>$ formulate strategies and plans for socio-economic development based on their own strengths, taking into account risks;

$>$ implement innovative programmes and projects that would adapt world experience and best practices;

$>$ use innovative management, effective inter-municipal cooperation and partnership (Gender-oriented budgeting in Ukraine: theory and practice, 2016).

Measurement of the degree of influence resulting from the development of budget funds for the accomplishment of tasks is a key element of gender-oriented budgeting (GOB). The main question in assessing the gender impact of planned budget measures is whether relevant (appropriate, adequate) measures have been taken to achieve the goal. The starting point for such an assessment is to compare existing resources and services required.

The analysis of the gender impact of interventions caused by the gender budgeting process involves studying the effect of the proposed budget allocations on the socioeconomic potential of women and men, and includes: an analysis of the socioeconomic impact on particular gender groups, a possible analysis of losses without implementing the proposed interventions, an analysis of risks during the implementation of the planned intervention.

An assessment of the gender impact of the planned budget measures should be carried out on an annual basis through reports on the activities of public institutions, which will focus on the results achieved and the efficiency of using budget funds, and not only on the statement of the targeted and full use of budget funds, as it usually happened (Gender-oriented budgeting in Ukraine: theory and practice, 2016).

A Strategy for reforming the public finance management system approved by the government for 2017-2020 identified the main directions of the development of the public finance management system, in particular, compliance with the general fiscal discipline in the medium term, increasing the efficiency of the resources allocation at the level of state policy formation, interbudgetary relations and fiscal decentralization, ensuring effective budget execution, increasing transparency and accountability in public finance management. Implementation of the Strategy will create conditions for sustainable economic growth of the state and ensuring macroeconomic stability, improving the quality of public services and the efficiency of public investment, as well as implementing reforms in other areas. It should also be noted that the issue of further development of the local financial management system at the level of the united community is one of the key issues in the Strategy. Particular attention is paid to the programme-target forecasting method (Strategy for reforming the public finance management system for 2017-2020: the order of the Cabinet of Ministers of Ukraine from 08.02.2018).

The Budget Code of Ukraine provides for the first time the establishment of a link between the financing of the budget programme and the final socially significant results expected from its implementation. In particular, starting from 2015, the main budget administrators, including those in the communities, are obliged to clearly determine the compliance of their budget programmes with strategic goals. At the same time, the effectiveness of this process remains questionable due to the lack of a coherent system of strategic planning and, first of all, sectoral strategic plans.

A large number of budget programmes developed by self-government bodies, their cumbersome structure do not give a clear understanding of what goals they are aimed at, spend budget funds for individual activities, 
the maintenance of premises and facilities, rather than the achievement of the strategic goal. The number of performance indicators is also too large, and they do not illustrate the results of the implementation of the budget programme, but record statistical data. All this does not allow making an objective assessment of efficiency and effectiveness. So, the results of the program-target method are not used when making managerial decisions. There is no effective control over the performance of budget programmes (Strategy for reforming the public finance management system for 2017-2020: the order of the Cabinet of Ministers of Ukraine from 08.02.2018; Budget Code of Ukraine, 2017).

The programme-targeted method, the use of which must be mandatory for budgets of all levels since 2019, should ensure optimal use of limited budget resources of the community in order to maximize the efficiency and quality of providing services for specific groups of women and men. At the same time, it is necessary to prove the effectiveness of spending budget funds with specifying the results for the public. Indicators of the performance of the main budget administrators should reflect the real socio-economic implications of policy implementation and the degree of strategic goals achievement in the relevant area. Further improvement of the system of effective indicators of budget programs should be aimed at strengthening their focus on coverage of the volume and quality of public services and the level of their recipient's satisfaction. In our opinion, the integration of a gender-oriented approach to the budget process will increase the efficiency and quality of the provided public services. Taking into account the needs of social groups, including gender, will increase the accountability of budget administrators and transparency of the budget, as required by the Budget Code, has to ensure effective evaluation of performance indicators with a view to timely making managerial decisions aimed at adjusting the activities of a budgetary institution to achieve the goals (Strategy for reforming the public finance management system for 2017-2020: the order of the Cabinet of Ministers of Ukraine from 08.02.2018; Budget Code of Ukraine, 2017).

The Strategy for the development of the public finance management system approved by the government identified the main ways of reforming the public finance management system in Ukraine that would directly integrate GOB into the public finance management system in Ukraine. This will ultimately help increase the efficiency of budget funds use and improve the state strategic planning model. In addition, GOB will contribute to a balanced development of society by securing interests and taking into account the needs of women and men, including from different social groups. It will increase the responsibility of main budget administrators for performance in relevant areas as well as the effectiveness of budget programmes (Strategy for reforming the public finance management system for 2017-2020: the order of the Cabinet of Ministers of Ukraine from 08.02.2018).

The full use of the programme-target method requires the accountability of the main budget administrators in front of the Verkhovna Rada of Ukraine for the achievement of the goals of fiscal policy. To achieve this goal the appropriate changes will be made to the Budget Code of Ukraine. They will provide the mandatory participation of main budget administrators at the stage of reporting on the implementation of the state budget for the previous year and consideration of the draft budget declaration for the planned and two subsequent periods, including the presentation of its strategic goals and reporting on their achievement. These changes should include deadlines and general procedures for the implementation of these powers by the main budget administrators (Budget Code of Ukraine, 2017).

Today, a comprehensive assessment of the efficiency and expediency of expenditures has been introduced to ensure saving and releasing resources for new priorities at the state level. It is expedient to analyze expenditures in order to identify inefficient or unnecessary ones and to increase the efficiency of implementing sectoral policies both at a state and community level.

Newly formed communities develop strategic documents, which determine the prospects and risks of development. In view of this, the optimization of budget programmes, the use of budget funds and their performance indicators should be based on the strategic goals of the main budget administrators and types of public services. Such a system is necessary to clearly reflect the level of achievement of strategic goals and benefits for recipients of public services, including through the introduction of a gender-oriented approach.

Any changes will not have sustainable results without an updated methodology for monitoring and evaluating the effectiveness of budget programmes to supplement performance and expenditures expediency analysis. As a result of such an assessment, appropriate management decisions will be taken to improve the quality of public services. The risks of introducing changes include political instability, the impossibility of carrying out all the reforms in synchrony (strategic planning, medium-term budget planning, programme-target method and public 
administration reforms) (Strategy for reforming the public finance management system for 2017-2020: the order of the Cabinet of Ministers of Ukraine from 08.02.2018).

The first steps in the power decentralization reform provided local governments with fiscal instruments to increase their own resources and to some extent reduced their dependence on central government in the financial sector. The funding of delegated powers has significantly increased. According to the results of the research conducted by the experts of the Financial Monitoring Group of the Central Office of Reforms under the Ministry of Regional Development (with the support of the Programme "U-LEAD with Europe" and SKL International) from 2014 to 2017, local budget revenues of Ukraine grew by 124 billion UAH. According to the forecasts for 2018, there is a tendency for their growth. In 2017, the total amount of financial resources available to local governments for the first time exceeded half of the consolidated budget of Ukraine and amounted to $51.2 \%$. The dynamics of revenues to the budgets of UTC outpaced the growth rate of income at other levels of local budgets. Receipt of own revenues of local budgets of 366 UTCs in 2017 grew by $87 \%$ and amounted to 9.3 billion UAH ( +4.3 billion UAH). And the rate of growth of own revenues of 159 UTCs, which already received in 2016 the enrollment of $60 \%$ of the individual income tax (IIT) to their budgets, is $+34.2 \%$ $(+1.1$ billion $\mathrm{UAH})$, which is almost $3 \%$ higher than the average indicator for Ukraine. The increase in revenues of the IIT amounted to $41.2 \%$, which is $1.9 \%$ more than in Ukraine as a whole. The financial capacity of local budgets is evidenced by the balances of funds available on the accounts as of January 1, 2018 in the amount of 55.7 billion UAH (State website of the Decentralization).

However, today most of the territorial communities are not able to independently fulfill all their own and delegated powers envisaged by law. The reason for this is the general instability of the interbudgetary relations system that does not fulfill its main functions: balancing local budget revenues and expenditures in the short term, financial equalization, in the medium term, stimulating the sustainable long-term development of communities in the long run.

The consequences of the instability of the interbudgetary relations system in Ukraine are as follows:

$>$ the list of expenditures of local budgets remains suboptimal, in particular, the lists and volumes of expenditures for the implementation of delegated and own powers are not organized; the mechanism for calculating expenditures for the implementation of delegated powers is ineffective;

$>$ the financial capacity of local self-government bodies is insufficient, which, given the limited access to financial markets, leads to tight budget constraints when exercising its own powers, restrains investment development of communities;

$>$ the existing budget policy tools of local self-government bodies do not provide opportunities for operational management of budget funds, optimization of the budget institutions network, the introduction of medium-term budget planning, calculation of real volumes and cost of public services, free access to loan capital;

$>$ there is no adequate financial transparency and reporting of local self-governments to territorial communities, as well as mechanisms of independent external audit and public oversight of the management of local finance and communal property (Strategy for reforming the public finance management system for 2017-2020: the order of the Cabinet of Ministers of Ukraine from 08.02.2018; Budget Code of Ukraine, 2017).

One of the tasks of the change in financial management is to increase the financial capacity of the territorial communities to the level of achieving the goals of sustainable local development on the principles of subsidiarity, universality and financial self-sufficiency. The main elements of the system should be the legally defined separation of state and self-government powers with appropriate allocation of resources. The process will encourage the local self-governments to strengthen their own fiscal base, introduce modern methods of financial management, including the use of elements of the gender-oriented approach. At the same time, a sectoral decentralization in the field of education, health care and social protection will take place. It is aimed at increasing accessibility, improving the quality and reducing the cost of public services, taking into account the real needs of social groups, including gender, optimizing the network of budget institutions, improving efficiency and Effectiveness of expenditures of local budgets property (Strategy for reforming the public finance management system for 2017-2020: the order of the Cabinet of Ministers of Ukraine from 08.02.2018).

Under the conditions of political tension, the need for a clear separation of powers between the state authorities and local self-government bodies is urgently needed. 
Corresponding changes should be made to the regulatory acts, which determine the distribution of powers between the central executive authorities and local self-government bodies, set the rates of deductions to local budgets, as well as the calculation of volumes and methodology for allocating subventions between local budgets. The implementation of this task also requires the introduction on a regular basis of consultations between central executive authorities and all-Ukrainian associations of local self-government bodies concerning the tasks of fiscal policy, delegated powers, and their financial support in the short and medium term.

One of the main tasks of the decentralization reform is the introduction of modern approaches to the management of finances, increase of own financial resources of the local self-government bodies.

Strengthening the resource base of local self-government provides the implementation of a number of legislative initiatives to allocate deductions from state taxes for local governments, to introduce a system of inventory of property and property rights, and to improve the methodology of valuation of land plots for the purpose of effective taxation of immovable property, to create an effective mechanism for repayment of tax debt. Extending the powers of local self-government bodies in administering and controlling the payment of local taxes and fees ensures that local councils are empowered to set rates in a wide range, to establish tax breaks and preferences, and to implement the principle of the universality of the tax base (State website of the Decentralization).

For the medium term, the state is expected to improve the methodology of equalization of tax capacity, which will focus on reducing the differentiation of budget security of communities, the formation of balanced local budgets, creating incentives for increasing the tax potential of territories and rational use of funds, as well as ensuring equal access of the population to public services in the amount and quality guaranteed by the state. Self-government should be prepared to the fact that the Ministry of Finance will review the methodology of calculation, terms and order of distribution, as well as the procedure for the use of funds of educational, medical and social subventions to increase the transparency of the process, extend the powers of local self-government bodies and strengthen control over the implementation of projects and programmes, financed by subventions. Together with the reform of sectoral decentralization in education, health care and social protection, this will ensure a gradual transition from maintaining the network of institutions to the procurement of public services with phased optimization of networks in the relevant sectors. Improving the legislation on the optimization of the number of benefits and the list of privileged categories of citizens, with the subsequent transition to targeted cash aid, is important for communities, if they take over the authority of the social sphere that is sensitive to a significant number of citizens (Strategy for reforming the public finance management system for 2017-2020: the order of the Cabinet of Ministers of Ukraine from 08.02.2018; Budget Code of Ukraine, 2017).

The Ministry of Finance plans to develop and approve methodological recommendations for drawing up medium-term forecasts of local budgets, coordinated with the methodology of the medium-term planning of the state budget, implementation of which will be provided by the local self-government bodies. And the Ministry of Finance will monitor compliance with these recommendations. A prerequisite for this task is to strengthen the institutional capacity of the local self-government bodies and to raise the level of skills of local government officials on medium and long-term planning, analysis of fiscal policy, preparation of investment projects, budget programmes with further analysis of their implementation (Strategy for reforming the public finance management system for 2017-2020: the order of the Cabinet of Ministers of Ukraine from 08.02.2018; Budget Code of Ukraine, 2017).

Enhancing the capacity of the local government bodies to borrow and to manage a local debt requires the development and approval by the Ministry of Finance of methodological recommendations for the local government bodies concerning the management of local debt. Strengthening the analytical and managerial capacity of the local financial institutions for capital market operations and debt management envisages increasing the competence of local government employees in assessing the creditworthiness of communities, procedures for the provision and monitoring of local guarantees, risk management and debt management methods.

A prerequisite for enhancing the transparency and accountability of local self-government bodies is the introduction of amendments to the regulatory acts on the organization and procedure for monitoring, supervision and control over the implementation of local budgets. Such changes should include clarification of the powers of the state financial control bodies regarding local budgets, revision of the control powers of local financial bodies (internal control and audit), unification of approaches to audit of local budgets by the state financial control bodies and independent external auditors. The fulfillment of this task also requires the introduction of a permanent mechanism of public control over the management of local finances and communal property. 
The risks that can prevent the reform are:

lack of political will to implement unpopular initiatives;

$>$ deepening the disproportions of the socio-economic development of territories as a result of the formation of territorial communities with higher economic potential with the subsequent conflict of interests regarding the redistribution of powers and financial resources;

$>$ reduction of the quality of management at the level of local self-government bodies due to the insufficient level of competence of local self-government officials, and the impossibility to increase their qualification in reforming the public finance management system (State website of the Decentralization).

In Ukraine, the introduction of gender-oriented budgeting as an important element of the effective regulation of financial resources takes place "from the bottom" - local initiatives supported by international donor organizations, and "from the top" - the programme-targeted method of forming the use of community financial resources implies the use of gender-sensitive indicators to assess the effectiveness of using funds.

A successful example of cooperation between the state and the donor organization is the project "Gender Budgeting in Ukraine" (Project GOB) receiving funding from the Swedish International Development Agency (SIDA). It was preceded by the pilot project "Gender-Oriented Budgeting at the Local Level in Ukraine" in 2012-2013, also funded by SIDA. It was devoted to gender analysis of the budgets of selected regional programmes, namely, youth and education programmes in Ivano-Frankivsk region and physical education and sports programmes in Luhansk region, with the purpose of developing practical tools and accumulation of experience at the regional level. The project aims to increase the economic efficiency of budget expenditures by taking into account the needs of individuals in both sexes (Official website of the GOB Project).

The project "Gender Budgeting in Ukraine" was initiated by the Ministry of Finance of Ukraine. The Ministry of Finance of Ukraine is the main beneficiary of the project and leads the process of implementation of the GOB. In addition, the project involves the relevant sectoral ministries, all regions and the city of Kyiv, and from 2017 - the united territorial communities.

In 2011, the Representation of the Friedrich Ebert Foundation in Ukraine (FEF) started implementation of the project "Gender Budgeting at the Local Level". The purpose of this project is to develop recommendations and provide a tool for implementing the gender component in the budget process. The project envisaged carrying out the gender analysis of local budgets, separate target and budget programmes and the development of gender budget initiatives based on their results. Since 2012, the Representation has been collaborating with the Programme "UN Women in Ukraine", which has supported the implementation of these initiatives in practice (Official website of the Friedrich Ebert Foundation in Ukraine).

The project was implemented in partnership with city councils and local public organizations. Within the project, 12 gender budget initiatives were initiated and implemented. Implementation of the project provided an opportunity to obtain Ukrainian experience in implementing the GOB, to assess the usefulness of this approach as an effective means of solving community problems, and to develop national methodological approaches to gender budgeting. In addition, the regional partners of the project, which implemented gender budget initiatives at the local level, have created an analytical center "Bureau of Gender Strategies and Budgeting".

The UN Women's Agency introduces the Programme "Increasing the Responsibility for Gender Equality Financing" for 2011-2015 in Ukraine. The programme was implemented in 15 countries in close cooperation with the European Commission, the International Training Center, the International Labor Organization and the Government of Spain. The aim of the programme was "to increase the volume and the efficiency of using donor assistance and national resources to meet national commitments on gender equality and empowerment of women" (Official website of the UN Women's Agency in Ukraine).

Since 2017, Global Communities has been operating in Ukraine with the five-year project "Decentralization Offering Better Results and Efficiency" (DOBRE) of the United States Agency for International Development (USAID). The DOBRE programme will direct the main part of the technical and financial assistance to the local level, including by creating conditions for the new UTCs in order to manage resources better, to improve the quality of utilities, to stimulate the local economy and to increase the citizens' engagement. The DOBRE helps UTCs through enhanced local self-governance and the creation of better conditions for development (Official website of the programme DOBRE). 
The DOBRE programme works in 7 target regions: Dnipropetrovsk, Ivano-Frankivsk, Kharkiv, Kherson, Kirovograd, Mykolaiv and Ternopil. The DOBRE provides direct assistance to 50 united territorial communities in these regions.

\section{Conclusions}

Introducing new approaches to state and regional governance in general and to the management of the financial resources of the united communities will strengthen the local self-government, deepen democracy and promote stability. The result of the decentralization reform should be a strong community whose sustainability is based on the community's internal needs and the cooperation of citizens with their local government in order to improve their lives. Partnerships between the civil society, the private sector and the government will bring tangible results, creating new economic opportunities and improving the management of local services for:

greater satisfaction of citizens with services;

$>$ improvement of service quality;

$>$ greater access of citizens to information;

$>$ improved transparency in operations and processes of the UTC;

$>$ increase community incomes from their own sources;

$>$ increased participation of citizens in UTC decision-making and other activities;

$>$ implementation of E-government tools in UTCs;

$>$ increase of trust in the UTC and confidence of citizens in its activities;

$>$ supporting the decentralization reform.

The governance model of the united communities has a special role in ensuring community control and accountability of local authorities. Public monitoring involves monitoring the planned results in terms of meeting the needs of each member of the community. In Ukraine, sufficient experience has been gained in applying public monitoring practices that can be introduced into the practice of local self-government bodies.

Thus, it can be concluded that the budget decentralization is a guarantee to decentralization of power, the establishment of an effective system of local finance, and most importantly, it is an instrument for regulating regional development. It is budget decentralization that involves encouraging regions to achieve financial autonomy, finding additional own resources, intensifying the internal development potential. It allows balancing the needs and capacities of the regions in general and of every citizen in particular.

Positive results. In our opinion, the reform of self-government is not sufficiently active, the regulatorylegislative base is not always harmonized. However, the course on strategic planning of particular financial resources proclaimed by the government, consideration of the "land" issue give grounds to rely on the intensification of decentralization processes. The issues of "separation" of the powers of the executive power vertical and presidential administrations, determination of the place of district councils upon completion of the reform remain open. The existing community experience needs to analyzed and systematized. Acquired experience of those who were the first has to minimize the negative consequences for the territories that are only on the way to unification.

\section{List of abbreviations:}

UTC - united territorial community;

GOB - gender-oriented budgeting;

IIT - individual income tax;

SIDA - Swedish International Development Agency;

FEF - Friedrich Ebert Foundation in Ukraine (

USAID - United States Agency for International Development;

DOBRE - Decentralization Offering Better Results and Efficiency.

\section{References}

1. Antoniuk, L. L. (2003). Innovatsiyi: teoriya, mekhanizm rozrobky ta komertsializatsiyi [Innovation: theory, mechanism of development and commercialization]: monograph. KNEU, 394 p.

2. Atamanchuk, G. V. (2001). Metodolohichni problemy suchasnoho derzhavnoho upravlinnya [Methodological problems of modern state administration]. Bulletin of the Ukrainian Academy of Public Administration, 3, 9-12.

3. Atamanchuk, G. V. (2004). Teoriya gosudarstvennogo upravleniya [Theory of public administration]: lecture course, $2^{\text {nd }}$ edition, Omega-L, $301 \mathrm{p}$. 
4. Budget Code of Ukraine (2017). Data. The Verkhovna Rada of Ukraine. No. 50-51, Art. 572.

5. Danylyshyn, B. M. Detsentralizatsiya u krayinakh YES: uroky dlya Ukrayiny [Decentralization in EU countries: lessons for Ukraine]. Regional economy, 1. Available at: http://nbuv.gov.ua/UJRN.

6. Danylyshyn, B. M. Detsentralizatsiya yak vymoha chasu: za Karpat $\cdot \mathrm{s}$ 'kym rehionom maybutnye [Decentralization as a requirement of time: the future of the Carpathian region], Ukraine economy, 1.9296. Available at: http://nbuv.gov.ua/UJRN.

7. Da Silva, M., Kurliandskaia, G. (2006). Razvitiye byudzhetnogo federalizma: mezhdunarodnyy opyt i rossiyskaya praktika [Development of budgetary federalism: international experience and Russian practice], Ves' Mir, p. 7.

8. Da Silva, M. et. al. (2009). Intergovernmental Reforms in the Russian Federation. Washington, D.C.: The World Bank.

9. European Charter for regional democracy (2008). Science-practice comment. Contributing authors: Bezverhniuk T. M. et al., Association of the state management researchers. KHOBBIT PLYUS, $186 \mathrm{p}$.

10.European Charter on local self-government (1997). Local self-government, 1(2), 70-77.

11.Gender-oriented budgeting in Ukraine: theory and practice (2016). Method. manual, individual entrepreneur Klymenko, 92 p.

12.Heiets, V. M. (2006). Innovatsiyni perspektyvy Ukrayiny [Innovative prospects of Ukraine]: monograph. Constant, $272 \mathrm{p}$.

13.Infrastructure of the regions of Ukraine. Priorities of the modernization. Analytical study (2017). NGO Foundation for International and Regional Studies of Poland, Friedrich Ebert Foundation, 108 p.

14.Ivchenko, V. (2009). Innovatsionnoye razvitiye - bezal'ternativnyy sposob resheniya sushchestvuyushchikh problem ukrainskoy ekonomiki [Innovatsionnoye razvitiye - bezal'ternativnyy sposob resheniya sushchestvuyushchikh problem ukrainskoy ekonomiki]. Strategy of innovative development of Ukraine for 2009-2020 in conditions of globalization challenges. Available at: http://www.uabanker.net/daily/2009/06/061809_1600.shtml.

15.Ivchenko, V. (2009). Osnovy stratehiyi rozvytku innovatsiynoyi systemy Ukrayiny [Fundamentals of the development strategy of innovation system in Ukraine]. State Agency of Ukraine for Investments and Innovations. Available

at: http://www.sadgora.cv.ua/content/view/173/34.

16.Karbovska, N., Lytvynova, T., Mahdiuk, L. (2010). Instrumenty intehruvannya kontseptsiyi gendernoyi rivnosti $\mathrm{v}$ roboti orhaniv mistsevoyi vlady [Tools for integrating the concept of gender equality into the work of local authorities].

17.Kolbasiuk, Yu. V., Vashchenko, K. O., Surmin, Yu. P. (2013). Modernizatsiya derzhavnoho upravlinnya ta yevropeys'ka intehratsiya Ukrayiny [Modernization of public administration and European integration of Ukraine]: scientific report, NASM, $120 \mathrm{p}$.

18.Kravchenko, T. A. (2015). Terytorial'na hromada yak pervynnyy sub"yekt mistsevoho samovryaduvannya: analiz suchasnykh naukovykh doslidzhen' v Ukrayini [Territorial community as a primary subject of local self-government: an analysis of modern scientific research in Ukraine]. State and regions: Scientific and Production Journal. Series "State regulation", 1(49), 68-75.

19.Law of Ukraine "On ratification of the European Charter of Local Self-Government" from 15.07.1997 No.452/97-BP (1997). Data. The Verkhovna Rada of Ukraine. No. 38, Art. 249.

20.Official website of the GOB Project. Available at: http://grbproject.org/.

21.Official website of the Friedrich Ebert Foundation in Ukraine. Available at: http://fes.kiev.ua/n/cms/.

22.Official website of the programme DOBRE. Available at: http://donors.decentralization.gov.ua/project/dobre.

23.Official website of the Ministry of Economic Development and Trade. Available at: http://openaid.gov.ua/uk/projects/7154.

24.Official website of the UN Women's Agency in Ukraine. Available at: http://www.un.org.ua/ua/informatsiinyi-tsentr/news/3053-2013-02-19-13-30-35-diyalnist-oon-zhinki-vukrayin.

25.Order of the President of Ukraine on the Sustainable Development Strategy "Ukraine - 2020" from 12.01.2015 No.5/2015 (2015). Official Bulletin of the President of Ukraine. No. 2, P. 14, Art. 154.

26.Project "Local Economic Development of Ukrainian Cities" (2012). On the path to gender equality. Information directory.

27.Prud'homme, R. (1995). The Dangers of Decentralization. The World Bank Research Observer, 10(2), 201-220. 
28.Regulsky, Jerzy (2014). U reformy mistsevoho samovryaduvannya bude bahato vorohiv [The reform of local self-government will have a lot of enemies]. Available at: https://lb.ua/society/2014/07/15/272846_lektsiya.html.

29.Sharko, M. V. (2004). Informatsiyna pidtrymka upravlins'kykh rishen' shchodo innovatsiynoyi diyal'nosti [Information support for managerial decisions on innovation activity], Economics and Forecasting: Scientific and Analytical Journal, 2, 131-138.

30.Sharko, M. V. (2005). Novyye organizatsionnyye formy innovatsionnykh predpriyatiy i vozmozhnosti ispol'zovaniya etikh form v Ukraine [New organizational forms of innovative enterprises and the possibility of using these forms in Ukraine]. Problems of Science: Interdisciplinary Scientific and Technical Journal, 8, 13-19.

31.Sokolenko, S. I. (2006). Stratehiya konkurentospromozhnosti ekonomiky Ukrayiny na osnovi intehratsiynykh system - klasteriv [The competitiveness strategy of the Ukrainian economy on the basis of integration systems - clusters], scientific dev. LLC "Ribest", 37 p.

32.Sokolenko, S. I. (2008). Innovatsiyni klastery - mekhanizm pidvyshchennya konkurentospromozhnosti rehionu [Innovation clusters - a mechanism for increasing the competitiveness of the region]/ Formation and development of regional clusters as one of the tools to enhance the competitiveness of the region: materials of the round table. Available at: http://ucluster.org/sokolenko/2008/07/innovacijny-klasteryregionu.

33.State website of the Decentralization. Available at: http://decentralization.gov.ua/.

34.Strategy for reforming the public finance management system for 2017-2020: the order of the Cabinet of Ministers of Ukraine from 08.02.2018 No. 142. Available at: http://zakon5.rada.gov.ua/laws/show/415$2017-\%$ D1\%80.

35.Vozniak, G. V. (2015). Perevahy ta ryzyky byudzhetnoyi detsentralizatsiyi: teoretyko-metodolohichni aspekty [The benefits and risks of budget decentralization: theoretical and methodological aspects]. Problems of the economy, 2, 253-257. Available at: http://www.problecon.com/pdf/2015/2_0/253_257.pdf. 